\title{
Change in Stream Flow of Gumara Watershed, upper Blue Nile Basin, Ethiopia under Representative Concentration Pathway Climate Change Scenarios
}

\author{
Gashaw Gismu Chakilu ${ }^{1, *}$, Szegedi Sándor ${ }^{2}$ and Túri Zoltán ${ }^{3}$ (i) \\ 1 Doctoral School of Earth Sciences, University of Debrecen, Egyetem tér 1, 4032 Debrecen, Hungary \\ 2 Department of Meteorology, University of Debrecen, Egyetem tér 1, 4032 Debrecen, Hungary; \\ szegedi.sandor@science.unideb.hu \\ 3 Department of Physical Geography and Geoinformatics, University of Debrecen, Egyetem tér 1, \\ 4032 Debrecen, Hungary; turi.zoltan@science.unideb.hu \\ * Correspondence: gashaw.gismu@science.unideb.hu
}

Received: 25 September 2020; Accepted: 27 October 2020; Published: 30 October 2020

\begin{abstract}
Climate change plays a pivotal role in the hydrological dynamics of tributaries in the upper Blue Nile basin. The understanding of the change in climate and its impact on water resource is of paramount importance to sustainable water resources management. This study was designed to reveal the extent to which the climate is being changed and its impacts on stream flow of the Gumara watershed under the Representative Concentration Pathway (RCP) climate change scenarios. The study considered the RCP 2.6, RCP 4.5, and RCP 8.5 scenarios using the second-generation Canadian Earth System Model (CanESM2). The Statistical Downscaling Model (SDSM) was used for calibration and projection of future climatic data of the study area. Soil and Water Assessment Tool (SWAT) model was used for simulation of the future stream flow of the watershed. Results showed that the average temperature will be increasing by $0.84^{\circ} \mathrm{C}, 2.6^{\circ} \mathrm{C}$, and $4.1^{\circ} \mathrm{C}$ in the end of this century under RCP 2.6, RCP 4.5, and RCP 8.5 scenarios, respectively. The change in monthly rainfall amount showed a fluctuating trend in all scenarios but the overall annual rainfall amount is projected to increase by $8.6 \%, 5.2 \%$, and $7.3 \%$ in RCP $2.6, \mathrm{RCP} 4.5$, and RCP 8.5 , respectively. The change in stream flow of Gumara watershed under RCP 2.6, RCP 4.5, and RCP 8.5 scenarios showed increasing trend in monthly average values in some months and years, but a decreasing trend was also observed in some years of the studied period. Overall, this study revealed that, due to climate change, the stream flow of the watershed is found to be increasing by $4.06 \%, 3.26 \%$, and $3.67 \%$ under RCP 2.6 , RCP 4.5 , and RCP 8.5 scenarios, respectively.
\end{abstract}

Keywords: climate change; stream flow; RCP; SWAT; Gumara watershed; Blue Nile

\section{Introduction}

Globally, there has been a considerable increase in emissions of greenhouse gas since the pre-industrial era, driven largely by population growth and different anthropogenic activities for economic development; these factors are now higher than ever [1]. Because of this unprecedented increase in concentrations of carbon dioxide $\left(\mathrm{CO}_{2}\right)$, methane $\left(\mathrm{CH}_{4}\right)$, and nitrous oxide $\left(\mathrm{N}_{2} \mathrm{O}\right)$ in the atmosphere, the global temperature is increasing [2]. The change in climate is evident and has become more clear since the 1950s, during which the extreme weather and climate events occurred [1], including the sea level rise through melting of ice and diminishing amounts of snow due to warm atmosphere and oceans [3]. Based on the observed weather and climate history, globally, the increase of mean surface temperature by the end of the 21stcentury (2081-2100) relative to 1986-2005 is expected to be $2.6{ }^{\circ} \mathrm{C}$ to $4.8{ }^{\circ} \mathrm{C}$ under the worst scenario (Representative Concentration Pathway (RCP8.5) [4]. 
The global increase of atmospheric temperature is observed in Ethiopia; the average temperature is expected to increase by $3.8^{\circ} \mathrm{C}$ by 2080 , and annual average minimum temperature has showed an increasing trend between $1951-2006$ by at least $0.37^{\circ} \mathrm{C}$ in every decade [5]. Historically, the amount of rainfall is also being changed, even though it is not showing a consistent trend spatially and temporally across the country [6]. According to the Intergovernmental Panel on Climate Change (IPCC) forecast, the amount of precipitation has showed a long-term increase in rainfall throughout the country [7], in the western parts of Ethiopia [8], and special seasonal increase during the last two months of Kiremt (rainy season) (August and September) and immediately after the Kiremt in the upper Blue Nile basin, Ethiopia [9].

The impact of climate change is much felt in water resources, through changing its availability globally [10].The change in both atmospheric temperature and rainfall significantly affect the state of the hydrological cycle [11]. The number and distribution of population is affected by scarcity of water due to the reduction of river flow and ground water recharge because of climate change. Due to this, around the world, approximately one-third of the population lives in the water stress countries, and it is also forecasted that in 2025 two-thirds of the world's population will be suffering by the water scarcity problem [12]. In Ethiopia, hydrological drought during dry seasons and flooding in rainy seasons has become a common problem in many perennial rivers. The hydrology of headwater catchments of the upper Blue Nile basin in Ethiopia has been influenced by climate change [13]. One of the researches conducted in Gilgel Abay, located in upper Blue Nile basin and the adjacent watershed to the study area, shows that stream flow is affected by climate change in terms of the seasonal influence; the effect is more prominent in Kiremt (rainy season) and Belg (small rainy season) than the dry season flow condition [14].

The study area of this research is one of the tributaries feeding in to the Lake Tana, which is the source of the Blue Nile River where the Grand Ethiopian Renaissance Dam is being constructed. The flow of this catchment prominently plays a role on water balance of the Lake Tana and the newly constructed dam as well. Therefore, this study has been designed to reveal the impact of future climate change on the stream flow nature of Gumara watershed under Representative Concentration Pathway (RCP) climate scenarios.

\section{Data and Methodology}

\subsection{Study Area Description}

The Gumara River is located in Lake Tana basin and upper Blue Nile basin; it is located to the east of the Lake Tana and extends between latitudes of $11^{\circ} 35^{\prime}$ and $11^{\circ} 55^{\prime} \mathrm{N}$ and longitudes $37^{\circ} 40^{\prime}$ and $38^{\circ} 10^{\prime} \mathrm{E}$. The Gumara catchment has a total drainage area of $1271.86 \mathrm{~km}^{2}$ up to the gauging station (near Woreta), $25 \mathrm{~km}$ before it joins the lake. The main stream starts from Guna Mountain; the total length is $132.49 \mathrm{~km}$ (approximately) before it joins Lake Tana. According to [15] agro climate zone classification, Gumara watershed is found in between Dega (cool and humid) and Woina Dega (cool and sub humid) climate zones; the upper part of the catchment has Dega and the lower part has Woina Dega climate zone condition, and the average annual rainfall is $1455.66 \mathrm{~mm}$ (Figure 1).

\subsection{Hydro-Climatic and Spatial Datasets}

Historically, observed weather data of stations in and near the study area were collected from NMA (National Meteorological Agency) of Ethiopia. The precipitation, maximum temperature, and minimum temperature, which were basically needed for both climate and hydrological models, were collected in five stations, whereas the other meteorological data like wind speed, relative humidity, and sunshine hour were available in only two stations. As it is common in other parts of the country, meteorological stations are sparsely distributed across the study area and not all stations have long-time historical data. Climate model variables or predictors were obtained from the Canadian Climate data and scenario website (http://climate-scenarios.canada.ca/?page=main). 


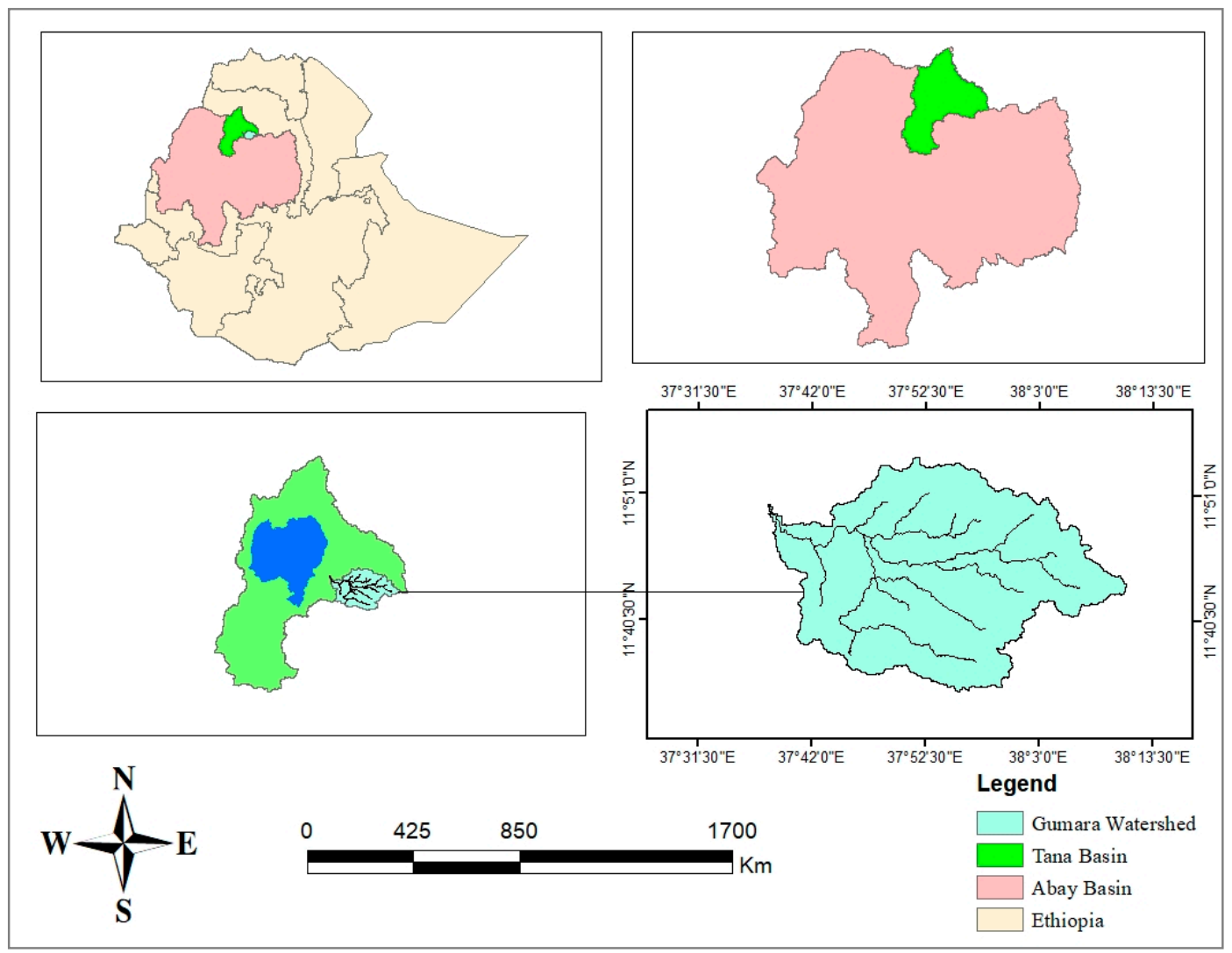

Figure 1. Location map of study area.

Recorded stream flow data of Gumara River were collected from Ministry of Water Irrigation and Energy (MoWIE) of Ethiopia. The time series of collected stream flow data was for the period of 1985-2008 (24 years).

Digital Elevation Model (DEM), Shuttle Radar Topography Mission (SRTM) (30m ×30m resolution), and Land use/cover data were taken from USGS Earth explorer website (https://earthexplorer.usgs.gov/). The Land use coverage was extracted for the study area which has $73.33 \%$ Kappa statistic and $88.33 \%$ overall classification accuracy. The other important input for flow simulation model was soil data obtained from the Ministry of Water, Irrigation and Energy (MoWIE) of Ethiopia.

\subsection{Data Preparation and Bias Correction}

Prior to analysis, the collected raw data were prepared to eliminate errors and biases. There were some missing values in all stations and these were replaced by -99 , which is compatible for SDSM model used for climate projection, and for the SWAT model for simulation of future stream flow. The raw data were arranged in monthly basis and stacked to daily annual time series base so as to make it well suited for climate statistical downscaling and hydrological simulation models.

Predictor variables had been calibrated by observed station data, which are referred to as predictands, through statistically adjusting the value of parameters. This statistical correlation of parameters and predictands was done using SDSM model. This model has also produced the future projected data of precipitation, maximum temperature, and minimum temperature of the stations based on the calibrated parameters. Both the temperature and rainfall change were evaluated comparatively between the historical data (1961-1990), which was considered as baseline data, and three future 30 year time series datasets, represented as 2020s (2011-2040), 2050s (2041-2070), and 2080s (2071-2100). 


\subsection{SWAT Model Setup, Calibration, and Validation}

Like climate data, the raw data of stream flow had also been prepared to make it compatible with the SWATCUP2012 software for calibration process. SWAT model passes the process through six important steps in simulation of the stream flow. The six steps of modeling are (1) delineation of the basin and river network extraction, (2) Hydrological Response Unit (HRU) definition and analysis, (3) climate station and weather generation formation, (4) sensitivity analysis of parameters, (5) model calibration, and (6) model validation.

The river network merged in to SRTM DEM using the "burn in" method, and the basin was delineated into $24 \mathrm{sub}$ basins. Sub basins of the catchment were further divided into 184 Hydrological Response Units (HRUs) using the land use, soil and slope distribution process.

The observed 10 years of observed stream flow data (1985-1994) were used for model calibration; and verification of calibrated parameters was tested by 1995-2000 (six) years of observed stream flow data. The proportion of datasets used for calibration and validation of model parameters is nearly similar with the recommended, which is that $70 \%$ of dataset should be taken for calibration and 30\% for validation [16]. The calibration process was carried out using SWATCUP2012 software. Using this software, the calibration was run with 2000 iterations through automatically adjusting of values of selected parameters within the range of adjustment domain. Sensitive parameters which have significant influence on stream flow simulated by SWAT model were selected by the sensitivity analysis process. Selected parameters are similar with the previous study done by [17]. The model efficiency was evaluated by using statistical variables determining the fitness of simulated stream flow with observed data. Those statistical variables, NS (Nash-Sutcliffe efficiency) and RVE (Relative Volume Error), are shown in Equations (1) and Equation (2), respectively.

$$
\mathrm{NS}=1-\frac{\sum_{\mathrm{i}=1}^{\mathrm{n}}\left(\mathrm{Q}_{\operatorname{sim}(\mathrm{i})}-\mathrm{Q}_{\mathrm{obs}(\mathrm{i})}\right)^{2}}{\sum_{\mathrm{i}=1}^{\mathrm{n}}\left(\mathrm{Q}_{\operatorname{sim}(\mathrm{i})}-\overline{\mathrm{Q}}_{\mathrm{obs}}\right)^{2}}
$$

where $\mathrm{Q}_{\text {obs }}$ and $\mathrm{Q}_{\text {sim }}$ represent the observed and simulated daily stream flows, respectively, $\mathrm{n}$ refers to the number of days in the simulated or observed time series period. The overbar symbol indicates the mean value. The value of Nash-Sutcliffe efficiency (NS) ranges between 1 and $-\infty 1$; showing the best fit of the model or that the model simulates similar values of stream flow with the observed values. The value should be more than 0.5 to accept the model [18].

$$
\mathrm{RVE}=\frac{\sum_{i=1}^{n}\left(\mathrm{Q}_{\operatorname{sim}(\mathrm{i})} \mathrm{Q}_{\mathrm{obs}(\mathrm{i})}\right)}{\sum_{i=1}^{n} \mathrm{Q}_{\mathrm{obs}(\mathrm{i})}} \times 100 \%
$$

RVE indicates the ratios of the sum of differences in simulated and total observed value of stream flow to the total observed stream flow.

\subsection{Comparison of Stream Flow under RCP Scenarios}

Once the model had been calibrated by selected parameters and validation was carried out for the watershed, stream flow was simulated using those selected parameters and automatically adjusted values of parameters. Stream flow was simulated using historical climate data and future projected climate data under RCP2.6, RCP4.5, and RCP8.5 scenarios separately.

The impact of climate change on stream flow of the catchment under RCP2.6, RCP4.5, and RCP8.5 scenarios was evaluated by comparing the flow generated by projected climate data under those scenarios in 2020s, 2050s, and 2080s with the baseline period (1961-1990). The land use characteristics of the watershed is the other determinant factor for simulation of stream flow; but since the study is designed to indentify the impact of climate change alone, the same land use cover data with the baseline period was taken. 


\section{Results and Discussion}

\subsection{Simulation, Bias Correction, and Future Climate Data Projection}

Statistically downscaled climate data were compared with the observed data. The efficiency of SDSM model was evaluated, and the difference of simulated and observed maximum temperature and minimum temperature is shown in Figures 2 and 3, respectively. The difference between observed and simulated maximum temperature in the baseline period is more prominent in the wet season (June-September); whereas the difference on the remaining months is insignificant. The maximum variation is shown on June, which is $0.36{ }^{\circ} \mathrm{C}$. The minimum temperature of downscaled data showed positive difference in all months except August, October, and November. The maximum difference is $0.32{ }^{\circ} \mathrm{C}$, observed on March shown in Figure 3.

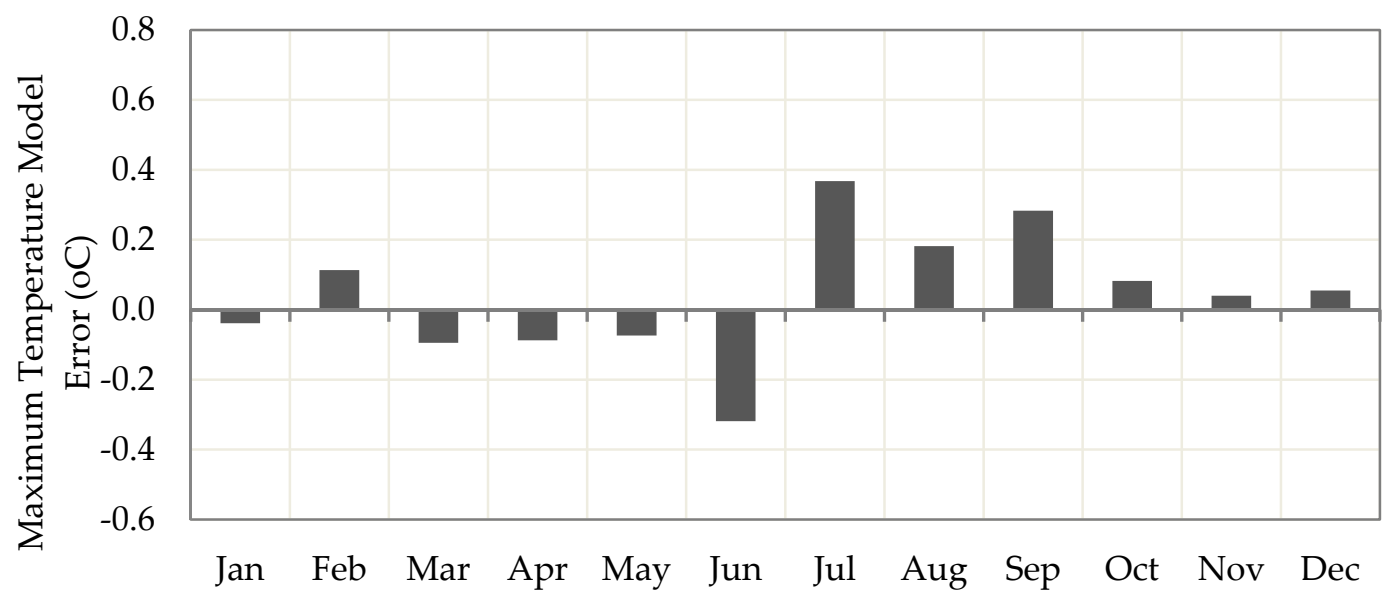

Figure 2. CanESM2 model error of maximum temperature for the baseline period (1961-1990).

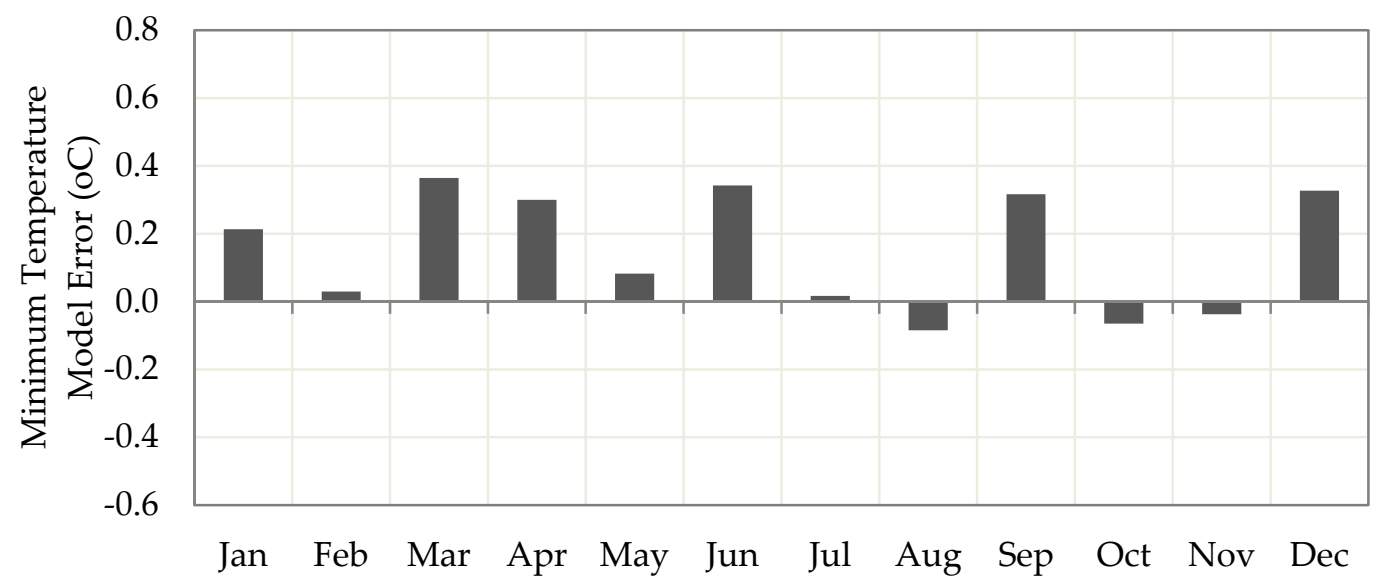

Figure 3. CanESM2 model error of minimum temperature for the baseline period (1961-1990).

The model cannot reasonably capture the observed rainfall of the baseline period in rainy season (June-September). Indeed, the change is significant in summer (rainy) season because rain is not common in the winter seasons in the study area. The change is negative at the beginning of the rainy season, and it is positive in the last two months of the summer season. The overall average difference between observed and downscaled rainfall data of the study area is $0.58 \mathrm{~mm}$ /day shown in Figure 4 . Statistical Down Scaling Model (SDSM) for CanESM2 climate model in RCP scenarios has been used by other researchers in the region and it has good fitness with the real data [19]. 


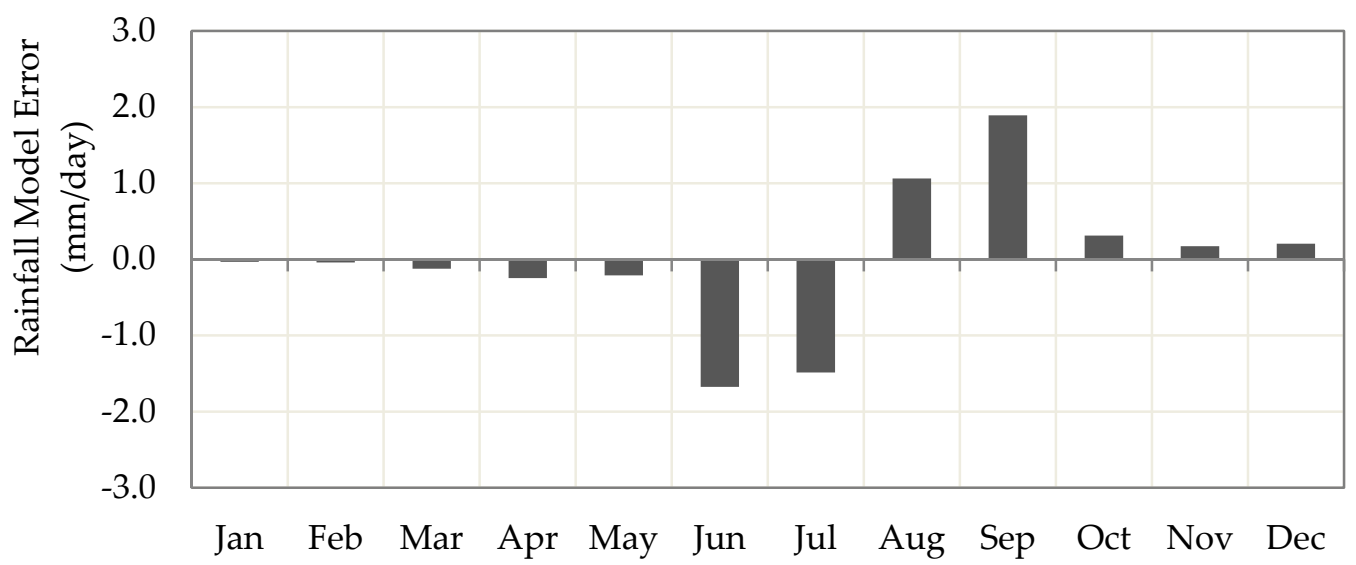

Figure 4. Model error of rainfall between observed and downscaled data of the baseline period (1961-1990).

\subsection{Calibration and Validation of SWAT Model}

The stream flow of the watershed was simulated using the SWAT hydrological model. Based on the sensitivity analysis which was conducted to determine parameters affecting the stream flow; 11 sensitive parameters were selected. Among these sensitive parameters, V_ALPHA_BF (base flow), and CN2 (curve number) were found to be the most sensitive parameters. The calibration process was carried out using the SWATCUP2012 software. The model was calibrated by model parameters, and those parameters with fixed value have also been validated. The efficiency was measured by NS and RVE, and the values of those statistical variables are $0.66 \%$ and $0.72 \%$, respectively. This fitness was also verified and it gives NS (0.63) and RVE (1.24\%). Thus, based on the values of those efficiency determinant variables, the model showed consistency with those optimized values of parameters on the study area and it is possible to say that these parameter values are representative of the Gumara watershed (Figure 5).

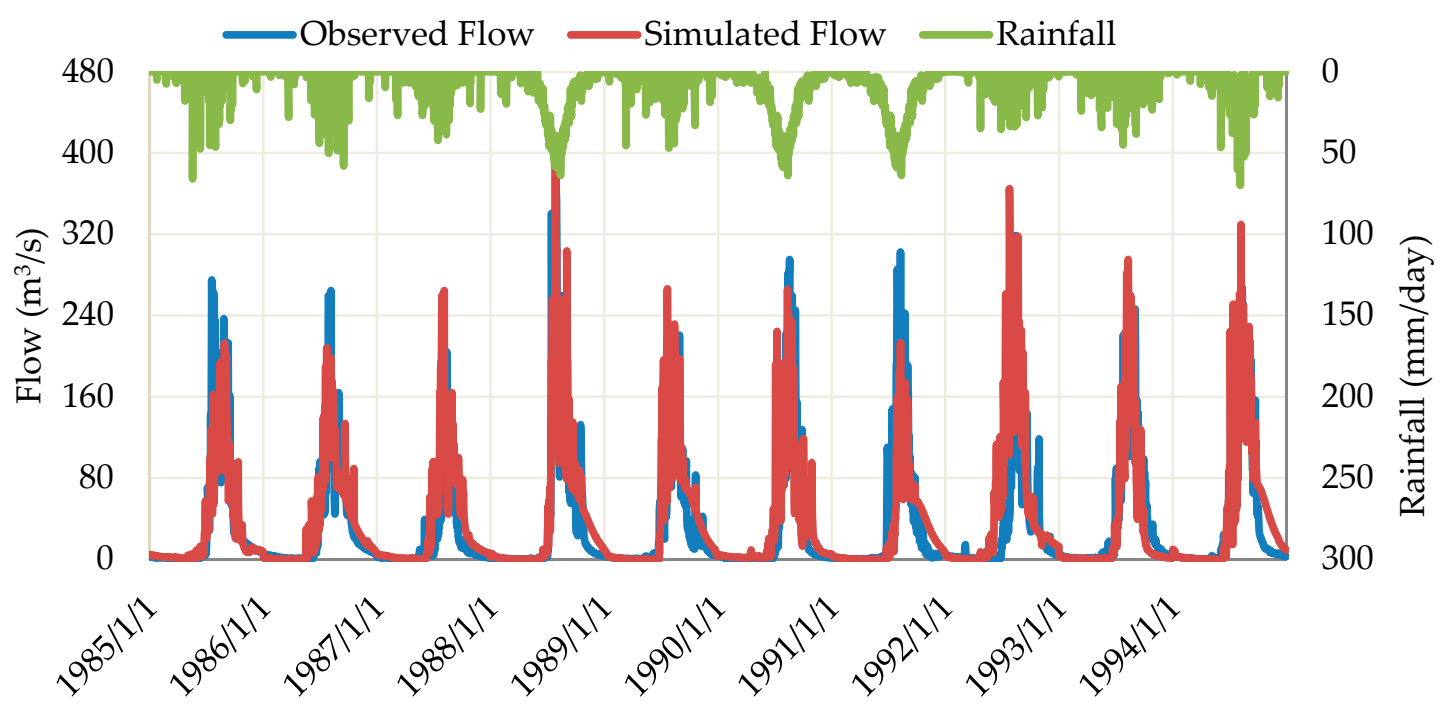

Figure 5. Comparison of simulated and observed flow for the calibration period (1985-1994).

The simulation flow in calibration period captures the peak flow in some years and it follows similar patterns, although in some years the simulated peak flow is above the peak values of observed stream flow and vice versa. In dry season, the simulated flow did not best captured the line; there is a light shifting to the right which shows that it is a little bit overestimated. In the calibration process, the model had good efficiency and the simulated flow closely followed the pattern of observed stream flow. Only three meteorological stations were used to represent the basin for this study; one 
of which is located out of the watershed, and the altitudinal variation of the study area is also very high. For this reason, the rainfall is extremely variable in terms of the spatial distribution within this area $[20,21]$, and the rainfall data used for the study may not be fully representative of the entire watershed. Therefore, this may have increased the spatial variability of runoff in the catchment, and hence some variations in peak flows of the simulated and observed flow were shown.

The calibrated parameters of the study area have been verified to measure their level of consistency by using six years of meteorological data (1995-2000). The simulated flow reasonably captured the peaks but also showed modest variation in dry season flows (Figure 6).

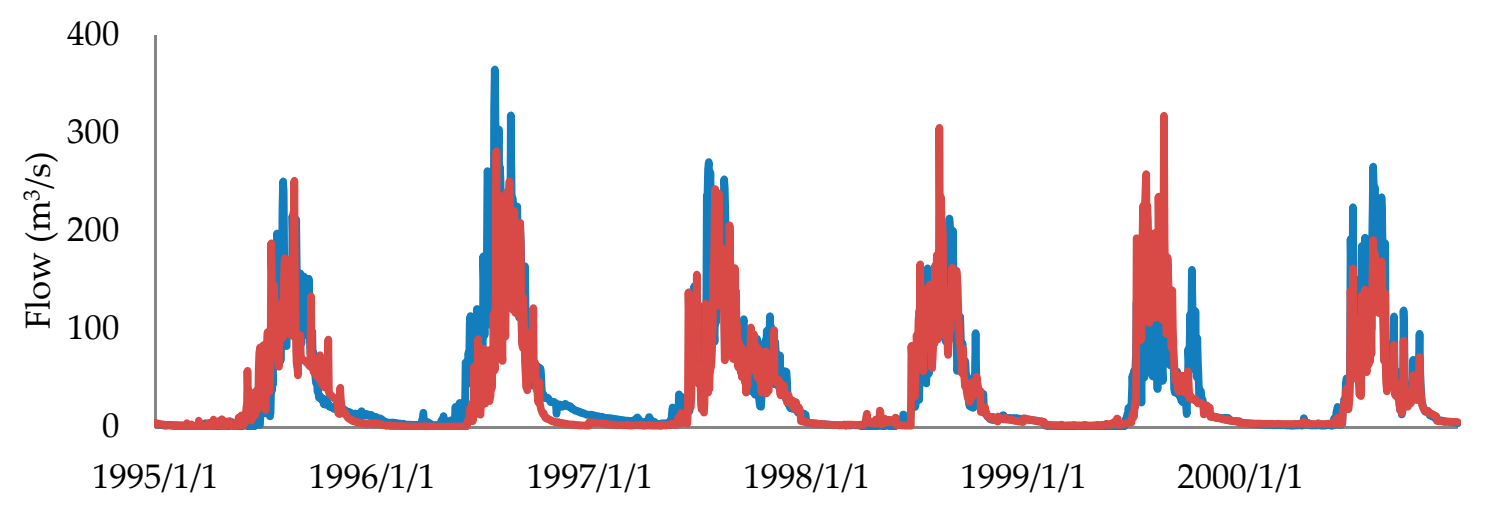

Observed Flow $\longrightarrow$ Simulated Flow

Figure 6. Comparison of simulated flow and observed flow for the validation period (1995-2000).

\subsection{Changes of Climate under RCP Scenarios}

The change of rainfall, maximum temperature, and minimum temperature based on RCP2.6, RCP4.5, and RCP 8.5 scenarios were analyzed in terms of monthly basis, because it is designed to reveal seasonal variation. The change was shown between the three phases of the whole period (2020s, 2050s, and 2070s) in which thirty years of time series is contained, compared with the baseline period (1961-1990).

\subsubsection{Change in Rainfall}

The average monthly rainfall in the study area for the whole period of this century has been forecasted under RCP 2.6, RCP 4.5, and RCP 8.5 climate scenarios. Under RCP 2.6 scenario, the maximum change of monthly average rainfall shows an increment of $38.21 \%$ in October and the minimum change is $-2.30 \%$ in November by 2080 s period, and the variability of changes observed within this range is shown in Figure 7. Under this climate scenario, almost all months, except two consecutive months (January and February), it is shown an increase in rainfall amount. The rainfall change under RCP 4.5 scenario ranges from $0.61 \%$ to $42.11 \%$ in both increasing and decreasing values, where the minimum value is observed in March within 2080s, and the maximum change is also in February but in the middle of 21st century (2050s), shown in Figure 8. In RCP 4.5 scenario, there is an increment in three consecutive months (August-November), whereas in the remaining months (e.g., December, May, June, and July) the change is not considerable. Like in RCP 4.5, the rainfall trend in RCP 8.5 exhibited a similar pattern, namely a fluctuating pattern in monthly bases even though both the upward and downward maximum change is relatively small compared with that of the RCP 4.5. The range of change is between $0.64 \%$ and $33.08 \%$ in increasing and decreasing values. The maximum change is observed in February within 2080s, shown in Figure 9. Even though different models were used, the result of this study is consistent with the findings of other studies near to Gumara watershed [22,23], and out of the region [24]. Moreover, the change in annual average rainfall in percent for the future time periods was found to be increasing for all scenarios, but when we compare the change between 
the three scenarios, the variation is not that considerable. Similar observations have been made in other parts of the world [25].

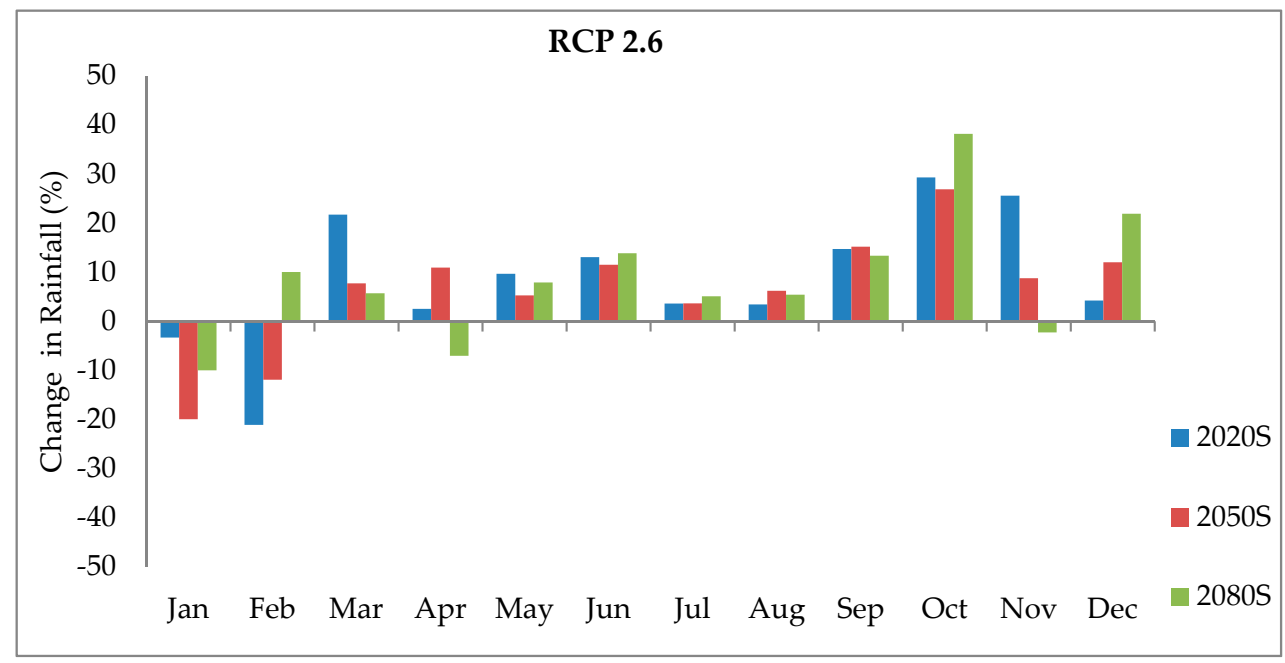

Figure 7. Change in rainfall under Representative Concentration Pathway (RCP2.6) scenario compared to the baseline (1961-1990).

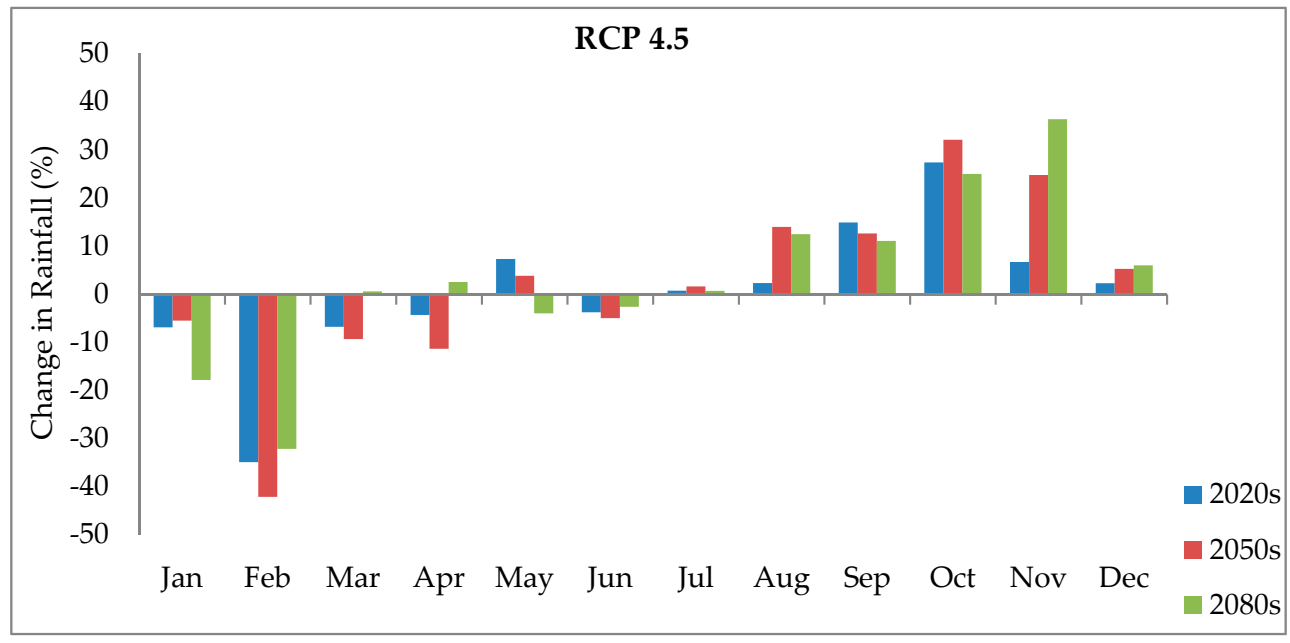

Figure 8. Change in rainfall under RCP4.5 scenario compared to the baseline (1961-1990).

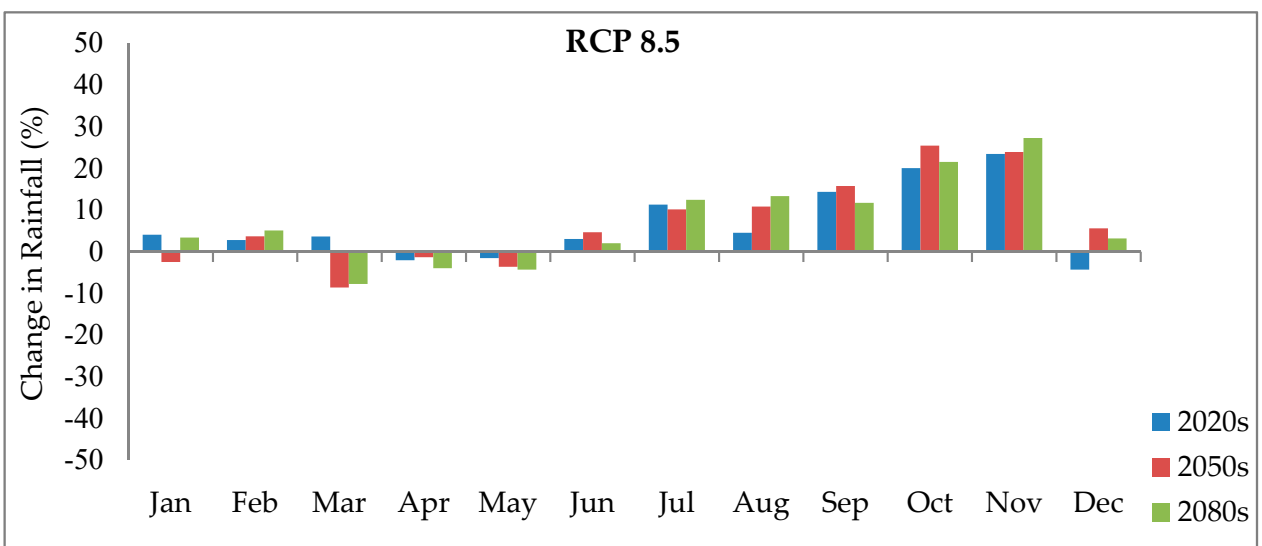

Figure 9. Change in rainfall under RCP8.5 scenarios compared to the baseline (1961-1990). 


\subsubsection{Change in Maximum and Minimum Temperature}

In this study, the change in the projected maximum temperature and minimum temperature of the three time frames compared to the baseline (1961-1990) period in all RCP scenarios was revealed. The change of maximum temperature in monthly average basis under the RCP 2.6 scenario varies between $0.26^{\circ} \mathrm{C}$ and $1.66^{\circ} \mathrm{C}$ in 2020s and 2080s, respectively, as shown in Figure 10. In this scenario, the maximum change in minimum temperature is $1.19^{\circ} \mathrm{C}$, which is observed in October 2080s. In RCP 4.5 scenario, the change in monthly average maximum temperature ranges from $0.51^{\circ} \mathrm{C}$ (December) to $3.38{ }^{\circ} \mathrm{C}$ (July), shown in Figure 10. The change in average maximum temperature at the end of this century under RCP 4.5 and RCP 8.5 scenarios is $2.6^{\circ} \mathrm{C}$ and $3.8^{\circ} \mathrm{C}$, respectively, shown in Figure 11. The change in monthly average minimum temperature under RCP 4.5 also ranges from $0.14{ }^{\circ} \mathrm{C}$ (August) to $2.67{ }^{\circ} \mathrm{C}$ (October), shown in Figure 12. Under RCP 4.5 and RCP 8.5 scenarios, the change in average minimum temperature is found to be increasing by $1.69^{\circ} \mathrm{C}$ and $4.02{ }^{\circ} \mathrm{C}$, respectively (Figure 13). The change in both maximum temperature and minimum temperature under RCP 8.5 was found to be increasing prominently compared with the other scenarios; the change in monthly average maximum temperature ranges from $0.42{ }^{\circ} \mathrm{C}$ in August to $4.96{ }^{\circ} \mathrm{C}$ in April, shown in (Figure 10). Climate Scenarios in RCP 2.6, RCP 4.5, and RCP 8.5 are developed with assumptions of having $2.6 \mathrm{~W} / \mathrm{m}^{2}$, $4.5 \mathrm{~W} / \mathrm{m}^{2}$, and $8.5 \mathrm{~W} / \mathrm{m}^{2}$ radiative forcing, respectively. Because of these concentrations of radiative forces, these scenarios are also assumed to be the cause for the change in average temperature by $1.5^{\circ} \mathrm{C}$ (RCP2.6), $2.4^{\circ} \mathrm{C}$ (RCP4.5), and $4.9^{\circ} \mathrm{C}$ (RCP8.5) [26], and the results of this study are consistent with this assumption. Moreover, the result of this study regarding the change in maximum and minimum temperature matches with that of other previous studies [27] near to the study area, and [28,29] out of the region.

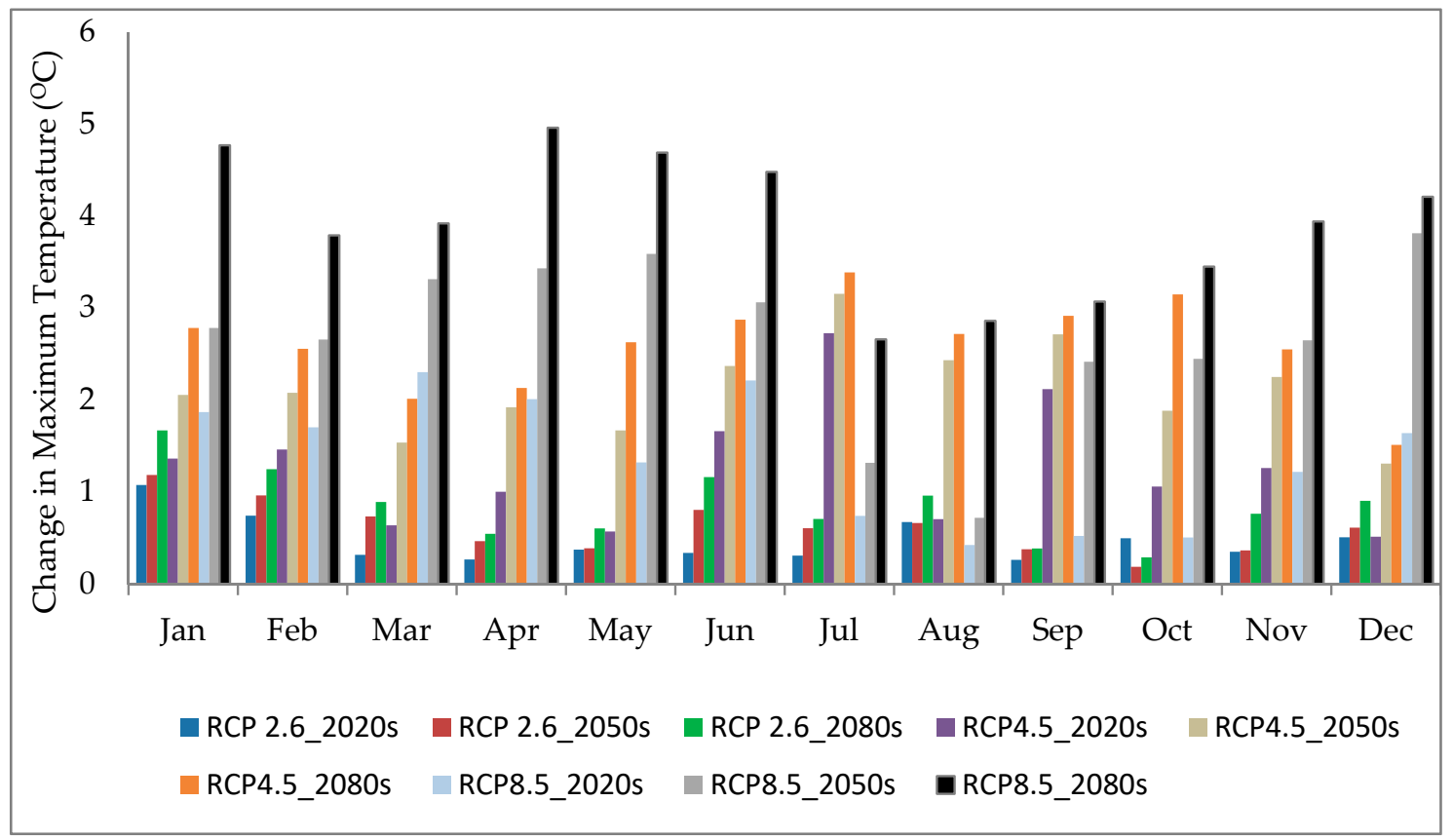

Figure 10. Change in monthly average maximum temperature compared to the baseline period (1961-1990). 


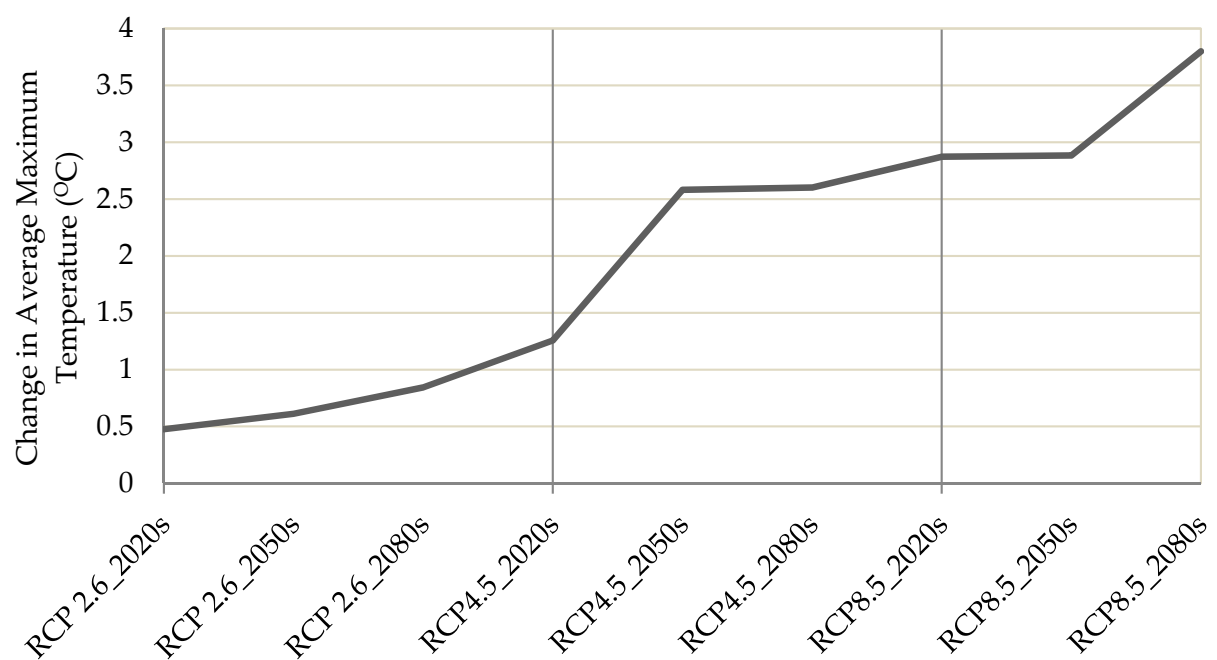

Figure 11. Change in annual average maximum temperature compared to baseline period (1961-1990).

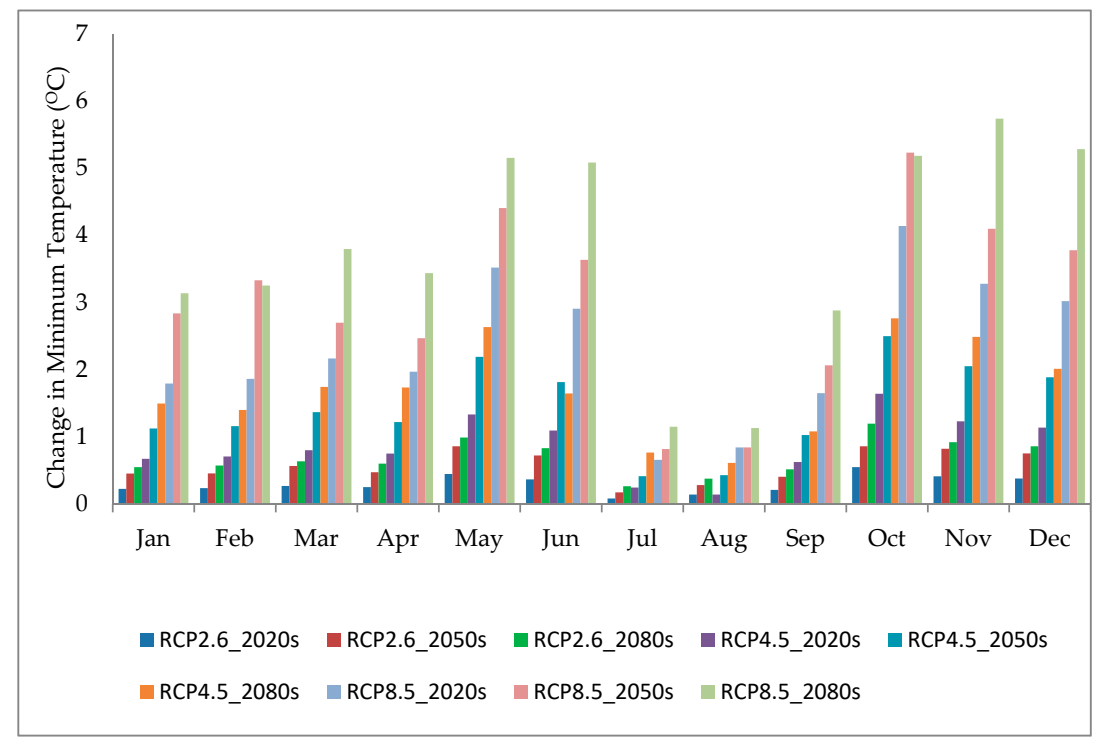

Figure 12. Change in monthly average minimum temperature compared to the baseline period (1961-1990).

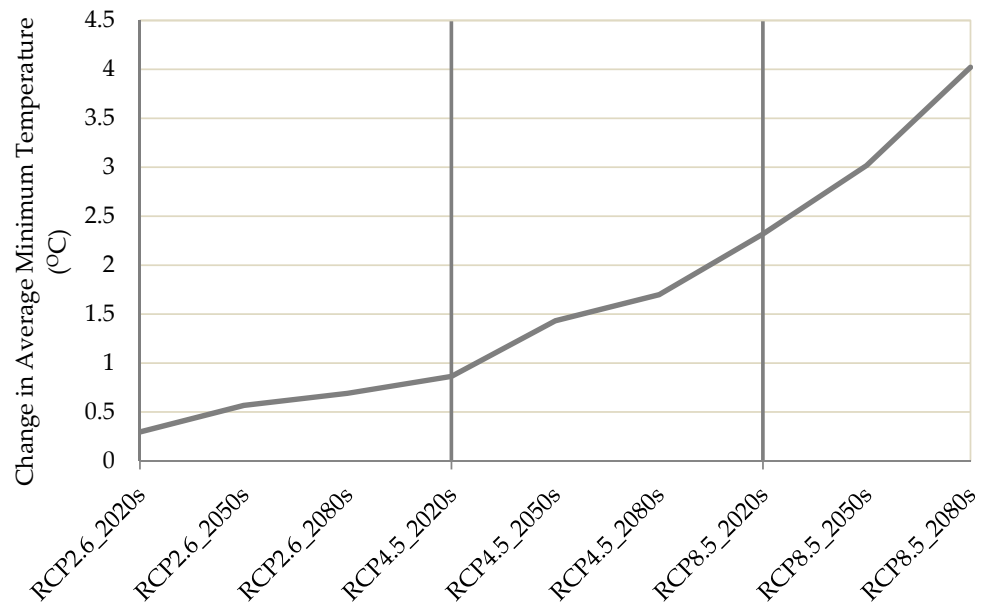

Figure 13. Change in annual average minimum temperature compared to the baseline period (1996-1990). 


\subsection{Evaluating Impact of Climate Change on Stream Flow}

The change in stream flow of Gumara watershed under RCP 2.6, RCP 4.5, and RCP 8.5 scenarios shows an increasing trend in monthly average values in some months and years, but a decreasing trend is also observed in some years of the studied period. In RCP 2.6 scenario, the change in stream flow was found to be increasing in almost all months other than January and February with some exceptions in 2080s, shown in Figure 14. The change under this scenario ranges from $1.11 \%$ in July 2020s to 19.18\% in August 2080s. In RCP 2.6 scenario, the average stream flow recorded an increment of $4.43 \%$ in $2020 \mathrm{~s}, 3.09 \%$ in $2050 \mathrm{~s}$, and $3.29 \%$ in $2080 \mathrm{~s}$; but the change is decreased between these three time frames. However, when considered on a monthly basis, the change in stream flow shows consistent increase under RCP 4.5 scenario. For example, the stream flow change increases in five consecutive months (July-November), whereas in the other months it shows decreasing with a small exception in May, shown in (Figure 15). The change ranges from $1.21 \%$ in May (period) to $20.97 \%$ in August (2080s). Due to this, the local farmers will not have adequate water for their irrigation agriculture; because they have been cultivating their land through diverting the dry season stream flow of Gumara River. Even though there is high variability between months, in RCP 4.5 scenario, the change in average stream flow is not considerable; it is $2.21 \%, 2.45 \%$, and $2.53 \%$ in 2020 s, 2050 s, and 2080s, respectively. Under RCP 8.5 scenario, the change in stream flow indicates insignificant increase in dry seasons but it is decreasing in the pre summer (rainy season), shown in Figure 16. The change in stream flow under all scenarios shows significant increase in summer and post summer (October and November) seasons, but in dry season due to the increase in temperature evapotranspiration will be increased [30], and consequently the catchment may be exposed to seasonal moisture deficit [31]. Moreover the average stream flow change in RCP 8.5 scenario is indicating $4.06 \%, 3.26 \%$, and $3.67 \%$ in 2020s, 2050s, and 2080s, respectively. The result of this study showed somehow consistency with previous results of research works conducted using different climate models and scenarios in the adjacent watersheds [27,32,33].

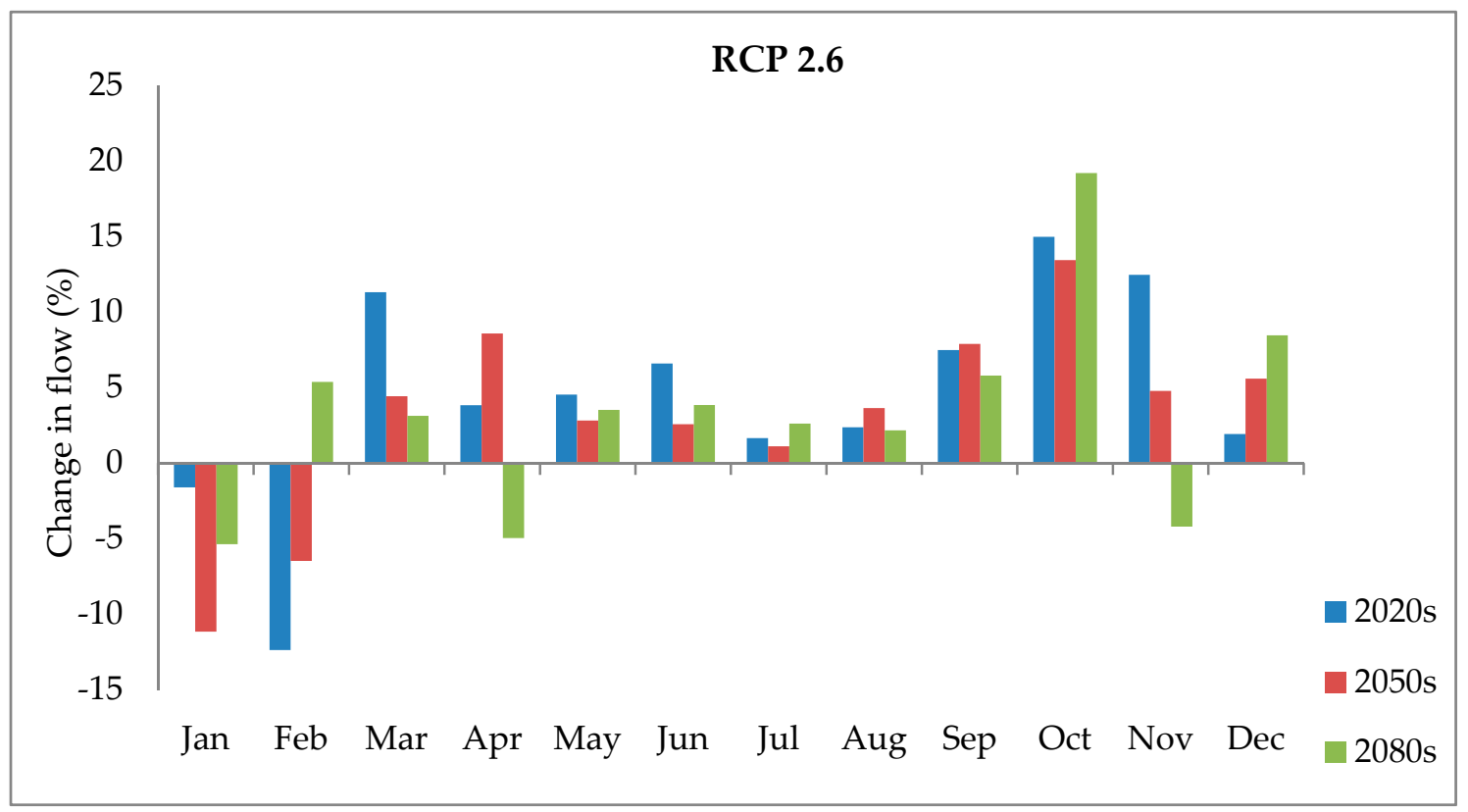

Figure 14. Change in stream flow under RCP 2.6 scenario compared to the baseline period (1961-1990). 


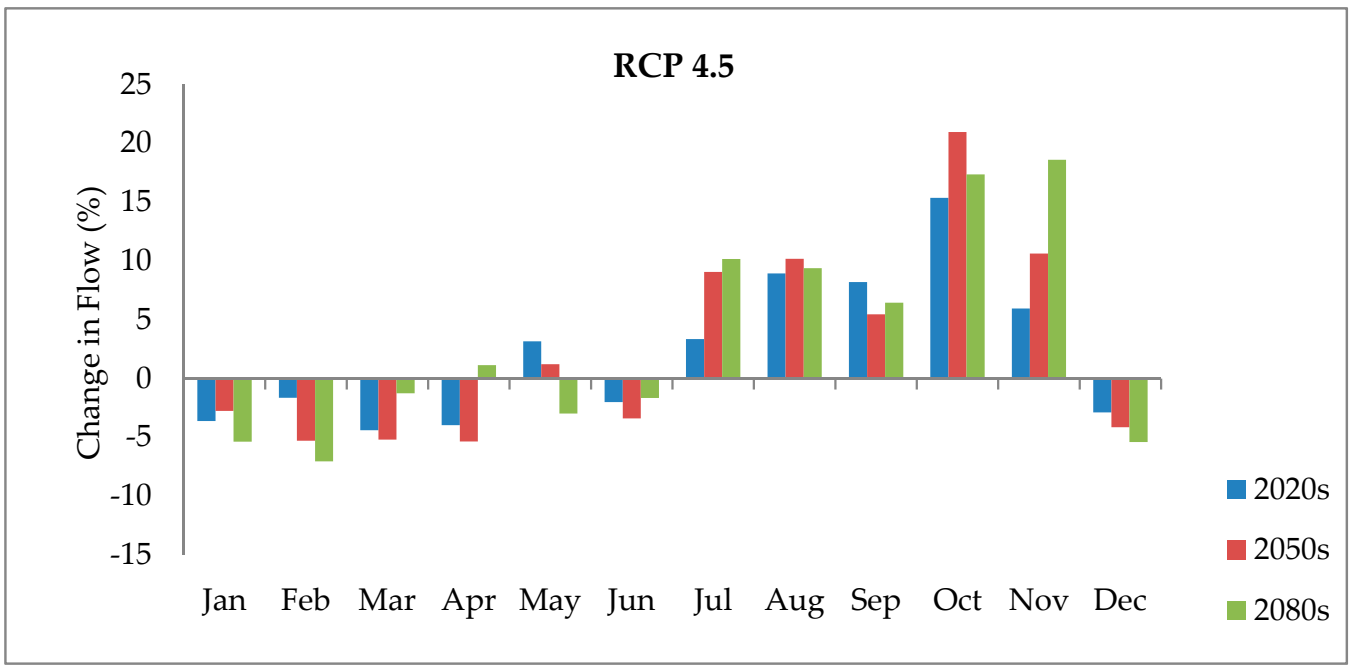

Figure 15. Change in stream flow under RCP4.5 scenario compared to the baseline period (1961-1990).

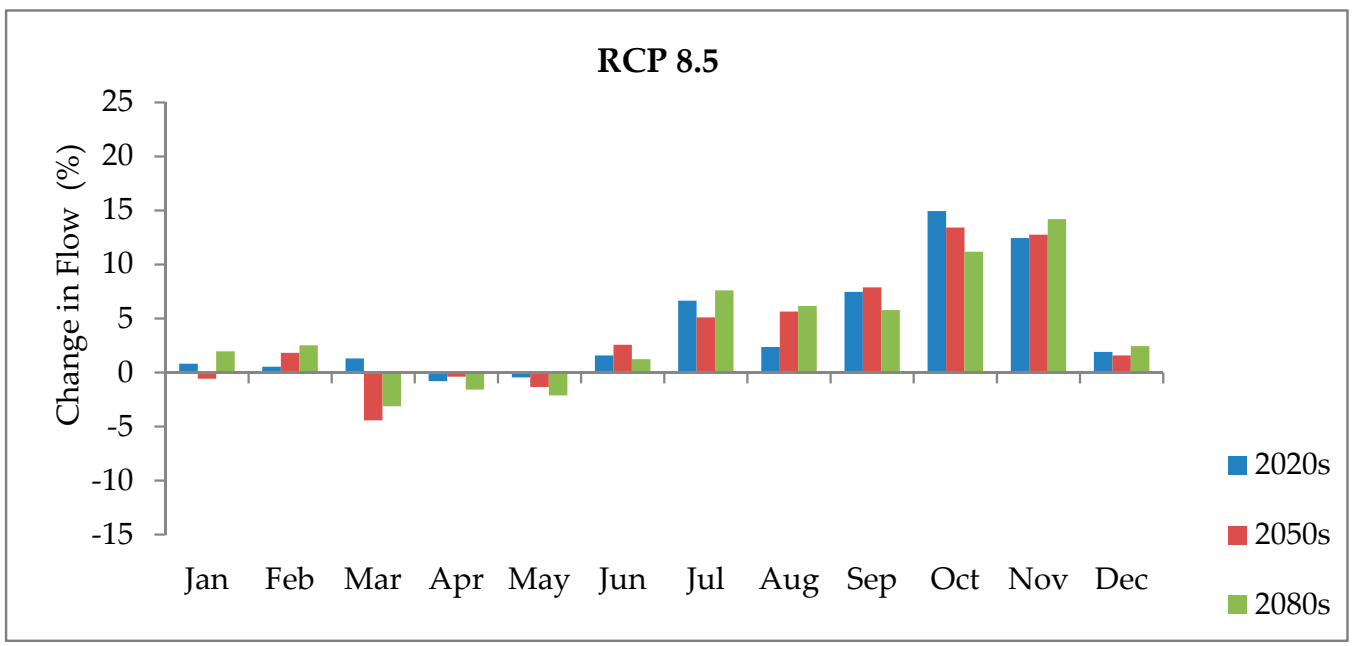

Figure 16. Change in stream flow under RCP 8.5 scenarios compared to the baseline period (1961-1990).

The change in temperature and rainfall will disturb the integrity of the whole ecosystems of the watershed, including the water ecosystems of lake Tana; and all its ecosystem services [34]. Therefore, physical soil and water conservation (watershed management) practices and biological conservation methods like afforestation and preserving the natural environment [35] should be executed on the upper catchment of the study area to reduce the impact of climate change, like flooding and sediment transport to the lake during rainy season and hydrological drought in dry season.

\section{Conclusions}

The future climate and its impact on the stream flow under Representative Concentration Pathway scenarios in the sub basin of Upper Blue Nile basin (Gumara watershed) were evaluated using CanESM2 climate model and statistically downscaling model. Stream flow of the study area was simulated by using SWAT model. The findings revealed that there is an increment in both maximum and minimum temperature under all scenarios in 2020s, 2050s, and 2080s with a higher rate of increase towards the end of the century. This leads toan increase in evapotranspiration and loss of moisture in the catchment. Even though there is no significant difference in the range and average change in rainfall between the three scenarios, the range of change in monthly average rainfall is somewhat higher under RCP 2.6 scenario than in other scenarios. The change in stream flow of Gumara watershed under RCP 2.6, RCP 4.5, and RCP 8.5 scenarios shows increasing trend in monthly average values in some months and 
years, but decreasing trend was also observed in some years of the studied period. Overall, the results of this study suggest that the change in climate under RCP 2.6, RCP4.5, and RCP8.5 scenarios has a strong bearing on the rate of the annual average stream flow, which increased by $4.06 \%, 3.26 \%$, and $3.67 \%$, respectively. Watershed management practices and preservation of natural environment should be done to mitigate the risk of climate change on the hydrological dynamics of the watershed.

Author Contributions: G.G.C. designed the hydrological model calibration and validation, downscaling of climate data, and writing of the paper. S.S. and T.Z. supervised the research and edited the paper. All authors have read and agreed to the published version of the manuscript.

Funding: This research was funded by EFOP-3.6.1-16-2016-00022 "Debrecen Venture Catapult program". The project is co-financed by the European Union and the European Social Fund.

Acknowledgments: We would like to thank National Meteorological Agency of Ethiopia (NMA), and Ministry of Water Irrigation and Energy (MoWIE) of Ethiopia for providing free input data for this research work. This paper is part of a PhD research project of the first author (G.G.C.) funded by the Tempus Public Foundation (Hungary) within the framework of the Stipendium Hungaricum Scholarship Programme, supported by Ministry of Science and Higher Education (MoSHE) of Ethiopia and Debark University.

Conflicts of Interest: The authors declare no conflict of interest.

\section{References}

1. Pachauri, R.K.; Allen, M.R.; Barros, V.R.; Broome, J.; Cramer, W.; Christ, R.; Church, J.A.; Clarke, L.; Dahe, Q.; Dasgupta, P. Climate Change 2014: Synthesis Report. Contribution of Working Groups I, II and III to the Fifth Assessment Report of the Intergovernmental Panel on Climate Change; IPCC: Geneva, Switzerland, 2014.

2. Hofmann, D.J.; Butler, J.H.; Dlugokencky, E.J.; Elkins, J.W.; Masarie, K.; Montzka, S.A.; Tans, P. The role of carbon dioxide in climate forcing from 1979 to 2004: Introduction of the Annual Greenhouse Gas Index. Tellus B Chem. Phys. Meteorol. 2006, 58, 614-619. [CrossRef]

3. Adopted, I. Climate Change 2014 Synthesis Report; IPCC: Geneva, Szwitzerland, 2014.

4. Hegerl, G.C.; Hoegh-Guldberg, O.; Casassa, G.; Hoerling, M.P.; Kovats, R.; Parmesan, C.; Pierce, D.W.; Stott, P.A. Good practice guidance paper on detection and attribution related to anthropogenic climate change. In Meeting Report of the Intergovernmental Panel on Climate Change Expert Meeting on Detection and Attribution of Anthropogenic Climate Change; IPCC Working Group I Technical Support Unit, University of Bern: Bern, Switzerland, 2010.

5. Tadege, A. Climate Change National Adaptation Program of Action (NAPA) of Ethiopia; National Meteorological Agency: Addis Ababa, Ethiopia, 2007.

6. Cheung, W.H.; Senay, G.B.; Singh, A. Trends and spatial distribution of annual and seasonal rainfall in Ethiopia. Int. J. Climatol. A J. R. Meteorol. Soc. 2008, 28, 1723-1734. [CrossRef]

7. EEA, J. WHO (2008): Impacts of Europe's Changing Climate-2008 Indicator-Based Assessment; European Environment Agency: Copenhagen, Denmark, 2008.

8. Bekele, L. Indications of the changing nature of rainfall in Ethiopia: The example of the 1st decade of 21st century. Afr. J. Environ. Sci. Technol. 2015, 9, 104-110.

9. Haile, A.T.; Akawka, A.L.; Berhanu, B.; Rientjes, T. Changes in water availability in the Upper Blue Nile basin under the representative concentration pathways scenario. Hydrol. Sci. J. 2017, 62, 2139-2149. [CrossRef]

10. Arnell, N.W. Climate change and global water resources. Glob. Environ. Chang. 1999, 9, S31-S49. [CrossRef]

11. Arnell, N.W. Climate change and global water resources: SRES emissions and socio-economic scenarios. Glob. Environ. Chang. 2004, 14, 31-52. [CrossRef]

12. Shiklomanov, I. Comprehensive Assessment of the Freshwater Resources and Water Availability in the World: Assessment of Water Resources and Water Availability in the World; World Meteorological Organization: Geneva, Switzerland, 1997.

13. Worqlul, A.W.; Dile, Y.T.; Ayana, E.K.; Jeong, J.; Adem, A.A.; Gerik, T. Impact of climate change on streamflow hydrology in headwater catchments of the Upper Blue Nile Basin, Ethiopia. Water 2018, 10, 120. [CrossRef]

14. Dile, Y.T.; Berndtsson, R.; Setegn, S.G. Hydrological response to climate change for gilgel abay river, in the lake tana basin-upper blue Nile basin of Ethiopia. PLoS ONE 2013, 8, e79296. [CrossRef] [PubMed]

15. Hurni, H. Agroecological belts of Ethiopia.Explanatory Notes on Three Maps at a Scale of 1:1,000,000; Wittwer Druck AG: Bern, Switzerland, 1998. 
16. Klemeš, V. Operational testing of hydrological simulation models. Hydrol. Sci. J. 1986, 31, 13-24. [CrossRef]

17. Chakilu, G.; Moges, M. Assessing the land use/cover dynamics and its impact on the low flow of Gumara watershed, Upper Blue Nile Basin, Ethiopia. Hydrol. Curr. Res. 2017, 8, 1-6. [CrossRef]

18. Nash, J.E.; Sutcliffe, J.V. River flow forecasting through conceptual models part I-A discussion of principles. J. Hydrol. 1970, 10, 282-290. [CrossRef]

19. Fenta Mekonnen, D.; Disse, M. Analyzing the future climate change of Upper Blue Nile River basin using statistical downscaling techniques. Hydrol. Earth Syst. Sci. 2018, 22, 2391-2408. [CrossRef]

20. Tilahun, K. Analysis of rainfall climate and evapo-transpiration in arid and semi-arid regions of Ethiopia using data over the last half a century. J. Arid Environ. 2006, 64, 474-487. [CrossRef]

21. Worqlul, A.W.; Yen, H.; Collick, A.S.; Tilahun, S.A.; Langan, S.; Steenhuis, T.S. Evaluation of CFSR, TMPA 3B42 and ground-based rainfall data as input for hydrological models, in data-scarce regions: The upper Blue Nile Basin, Ethiopia. Catena 2017, 152, 242-251. [CrossRef]

22. Taye, M.T.; Ntegeka, V.; Ogiramoi, N.; Willems, P. Assessment of climate change impact on hydrological extremes in two source regions of the Nile River Basin. Hydrol. Earth Syst. Sci. 2011, 15, 209. [CrossRef]

23. Seleshi, Y.; Zanke, U. Recent changes in rainfall and rainy days in Ethiopia. Int. J. Climatol. A J. R. Meteorol. Soc. 2004, 24, 973-983. [CrossRef]

24. Tahir, T.; Hashim, A.; Yusof, K. Statistical downscaling of rainfall under transitional climate in Limbang River Basin by using SDSM. In IOP Conference Series: Earth and Environmental Science; IOP Conference Series: Langkawi, Malaysia, 2018.

25. Phinzi, K.; Ngetar, N.S. Land use/land cover dynamics and soil erosion in the Umzintlava catchment (T32E), Eastern Cape, South Africa. Trans. R. Soc. S. Afr. 2019, 74, 223-237. [CrossRef]

26. Wayne, G. The beginner's guide to representative concentration pathways. Skept. Sci. 2013, 3, 25.

27. Kim, U.; Kaluarachchi, J.J.; Smakhtin, V.U. Climate Change Impacts on Hydrology and Water Resources of the Upper Blue Nile River Basin, Ethiopia; IWMI: Colombo, Sri Lanka, 2008; Volume 126.

28. Tan, M.L.; Yusop, Z.; Chua, V.P.; Chan, N.W. Climate change impacts under CMIP5 RCP scenarios on water resources of the Kelantan River Basin, Malaysia. Atmos. Res. 2017, 189, 1-10. [CrossRef]

29. Mishra, V.; Lilhare, R. Hydrologic sensitivity of Indian sub-continental river basins to climate change. Glob. Planet. Chang. 2016, 139, 78-96. [CrossRef]

30. Mengistu, B.; Amente, G. Reformulating and testing Temesgen-Melesse's temperature-based evapotranspiration estimation method. Heliyon 2020, 6, e02954. [CrossRef] [PubMed]

31. Komuscu, A.U.; Erkan, A.; Oz, S. Possible impacts of climate change on soil moisture availability in the southeast Anatolia development project region (GAP): An analysis from an agricultural drought perspective. Clim. Chang. 1998, 40, 519-545. [CrossRef]

32. Adem, A.A.; Tilahun, S.A.; Ayana, E.K.; Worqlul, A.W.; Assefa, T.T.; Dessu, S.B.; Melesse, A.M. Climate change impact on stream flow in the upper Gilgel Abay Catchment, Blue Nile Basin, Ethiopia. In Landscape Dynamics, Soils and Hydrological Processes in Varied Climates; Springer: Berlin, German, 2016; pp. 645-673.

33. Enyew, B.; Van Lanen, H.; Van Loon, A. Assessment of the impact of climate change on hydrological drought in Lake Tana catchment, Blue Nile basin, Ethiopia. J. Geol. Geosci. 2014, 3, 174.

34. Gaglio, M.; Aschonitis, V.; Pieretti, L.; Santos, L.; Gissi, E.; Castaldelli, G.; Fano, E. Modelling past, present and future Ecosystem Services supply in a protected floodplain under land use and climate changes. Ecol. Model. 2019, 403, 23-34. [CrossRef]

35. Mena, M.M.; Madalcho, A.B.; Gulfo, E.; Gismu, G. Community Adoption of Watershed Management Practices at Kindo Didaye District, Southern Ethiopia. Int. J. Environ. Sci. Nat. Resour. 2018, 14, 32-39. [CrossRef]

Publisher's Note: MDPI stays neutral with regard to jurisdictional claims in published maps and institutional affiliations.

(C) 2020 by the authors. Licensee MDPI, Basel, Switzerland. This article is an open access article distributed under the terms and conditions of the Creative Commons Attribution (CC BY) license (http://creativecommons.org/licenses/by/4.0/). 